\title{
MULTICRITERIA COMPROMISE OPTIMIZATION FOR LEATHER AND FUR SKIN MATERIALS TANNING TECHNOLOGY
}

\author{
Halyna YEFIMCHUK ${ }^{1 *}$, Vladyslava SKIDAN ${ }^{2}$, Mariya NAZARCHUK ${ }^{3}$, Eduard SELEZNOV ${ }^{1}$, \\ Anzhelika YANOVETS ${ }^{1}$
}

${ }^{1}$ Lutsk National Technical University, Lvivska Str., build.75, Lutsk, Ukraine, 43018, email: gefimchuk@gmail.com

${ }^{2}$ Kyiv National University of Technology and Design, Nemyrovych-Danchenko Str., build.2, Kyiv, Ukraine, 01011

${ }^{3}$ Lesya Ukrainka Eastern European National University, Voli Prosp., build.13, Lutsk, Ukraine, 43025

Received: 15.02 .2020

Accepted: 10.06 .2020

https://doi.org/10.24264/Ifj.20.2.9

MULTICRITERIA COMPROMISE OPTIMIZATION FOR LEATHER AND FUR SKIN MATERIALS TANNING TECHNOLOGY

ABSTRACT. The work is devoted to the study of the influence of electro-activated aqueous solutions on the technological cycle of leather and fur skin materials production and footwear made of them. The influence of electro-activated aqueous solutions on the physicochemical transformations of the structure of skin tissue collagen is exemplified by rabbit fur skins used for shoe production. The spectral characteristics of changes in the structure and chemical composition of dermal collagen are determined and optimal modes of tanning process of leather and fur skin materials based on multicriteria compromise optimization are determined.

KEY WORDS: electro-activated aqueous solutions, anolyte, catholyte, leather and fur skin materials, footwear

OPTIMIZARE MULTICRITERIALĂ A TEHNOLOGIILOR DE TĂBĂCIRE A PIEILOR ȘI BLĂNURILOR PRIN GĂSIREA UNEI SOLUȚII DE COMPROMIS REZUMAT. Lucrarea este dedicată studierii influenței soluțiilor apoase activate electrochimic asupra ciclului tehnologic al producției de piele și blană pentru încălțăminte. Influența soluțiilor apoase activate electrochimic asupra transformărilor fizico-chimice ale structurii colagenului din țesutul pielii este exemplificată prin piei cu blană de iepure utilizate pentru producerea încălțămintei. S-au determinat caracteristicile spectrale ale modificărilor în structura și compoziția chimică a colagenului din stratul dermic sunt determinate, precum și metodele optime de tăbăcire a pielii și blănii pe baza optimizării multicriteriale prin găsirea unei soluții de compromis.

CUVINTE CHEIE: soluții apoase activate electrochimic, anolit, catolit, piele și blană, încălțăminte

OPTIMISATION MULTICRITÈRES DES TECHNOLOGIES DE TANNAGE DU CUIR ET DE LA FOURRURE VISANT À TROUVER UN COMPROMIS RÉSUMÉ. Le travail est consacré à l'étude de l'influence des solutions aqueuses électro-activées sur le cycle technologique de la production du cuir et de la fourrure pour la production de chaussures. L'influence des solutions aqueuses électro-activées sur les transformations physicochimiques de la structure du collagène des tissus cutanés est illustrée par les fourrures de lapin utilisées pour la production de chaussures. On a déterminé les caractéristiques spectrales des changements dans la structure et la composition chimique du collagène dermique et les modes optimaux de processus de tannage des cuirs et des fourrures basés sur l'optimisation multicritère visant à trouver un compromis.

MOTS CLÉS : solutions aqueuses électro-activées, anolyte, catholyte, cuir et fourrure, chaussures

\section{INTRODUCTION}

Technologies that provide the manufacture of leatherandfurskinmaterialsimplytheretention of beneficial properties of both the skin tissues and its hair-covering, and ensure permanency of these materials during continuous exploitation of products made of them. The most toilful and time-consuming processes in the leather and fur skin manufacturing cycle are preparatory and tanning stages. These processes are carried out with significant water consumption, while water is acting as a solvent for chemical reagents, and their utilization requires significant costs in the future [1].

The most promising solution to the problem of reducing water consumption and material consumption of fur production are methods that activate chemical reagents in water such as usage of electric current. The effect of the latter is widely studied by a number of scientists [2, $3]$, but the nature and action mechanism of the water being treated by electricity has not been sufficiently studied yet.

Liquid processes in the production of leather and fur skin materials are fully associated with the presence in the water solution of electrolytes formed in the result of the dissociation of ions of chemical formations in the protein structure, hydrolysis of bonds, the carriers of which are structural elements of the protein, as well as relatively free ions. At the same time, ions introduced with water as a solvent *Correspondence to: Halyna YEFIMCHUK, Lutsk National Technical University, Lvivska Str., build.75, Lutsk, Ukraine, 43018, email: gefimchuk@
gmail.com. 
of chemical components, in particular $\mathrm{Na}^{+}+\mathrm{Cl}^{-}$ ions, are involved. Natural (tap) and distilled water has minimal electrical conductivity in its structure, and electro-activated water (anolyte and catholyte) has 2-3 times greater electrical conductivity, that indicates that the conductivity in these solutions is provided not only by $\mathrm{Na}^{+}+\mathrm{Cl}^{-}$ but also by ions formed by the excess of mobile ions with a positive or negative charge that may be carried by groups with water molecules.

One of the most common forms of polymeric material study is their physical and mechanical testing, as their physical and mechanical properties are widely used in light industry to evaluate the quality of fully processed products. Studies of the relaxation and deformation characteristics of materials are of considerable scientific and practical interest. The results of such experiments allow to record simultaneously during one experiment the following kinetic curves [4]: the curve of development and relaxation and deformation in the sample, changes in its linear dimensions and hygroscopicity.

It is known [5] that objects with complex curvilinear surface shape (foot, shoe pad, shoe upper parts) are of the greatest complexity for design, because anatomical structure of the foot and the properties of the leather and fur skin materials from which the footwear is made must be taken into account in order to ensure their proper quality. However, in the conditions of production of leather and fur skin materials, most often according to the existing technological schemes and instructions it is not possible to determine the optimal combination of technological factors by which in particular case it is possible to achieve the maximum approximation to the required properties of the prefabricated leather component at the minimum cost of chemical materials.

Solving the problems of optimization and mathematical modeling of complex technological systems is characterized by significant particular characteristics due to the narrow application orientation of the obtained solutions, sometimes by the lack of sufficient information about the mechanisms occurring inside the system. At the same time the solution of such problems leads to the random nature of the change of optimality criteria and some factors with a considerable number of quality indicators (optimization criteria) and as well as to factors that are taken into account in optimization and modeling [6].

The applied methodology for solving these problem classes provides various recommendations for the nature of this study. According to the classical, i.e. theoretical and analytical approach [7], it is recommended to obtain a mathematical model and then, using it, to find the optimal conditions.

\section{EXPERIMENTAL}

\section{Materials and Methods}

Rabbit skins that differ in the way they had been made were selected as the object of the study. Thus, for the manufacture of skins at all stages of the technological cycle electroactivated aqueous media was used. Skins, tanned by the standard technology were used to control the initial performance indicators of the dermis and to compare them.

The change in the structure and chemical composition of the rabbit dermis collagen was evaluated by the results of IR spectroscopy (Bruker TENSOR spectrometer) within the spectral range of $4000-400 \mathrm{~cm}^{-1}$. The test specimens were prepared in the form of a tablet which contained potassium bromine $(\mathrm{KBr})$ with a sample of ground tissue $0.5-1 \mathrm{mg}$. The IR spectra of the studied materials were described on the basis of reference data [8-10].

The IR spectra of rabbit skin tissue in the range of $3800-2600 \mathrm{~cm}^{-1}$ and $1800-400 \mathrm{~cm}^{-1}$ were studied. The nature of the interaction of the studied systems was evaluated by the disappearance, displacement and intensity change of the corresponding characteristics of bandwidths. The bandwidths in the IR spectra of the initial materials and the products of their interaction were assigned according to the bandwidths of the characteristic bonds of $\mathrm{C}-\mathrm{C}$ atoms group and $\mathrm{CH}_{2}$.

The influence of the electrical conductivity of water on the basic chemical parameters of rabbit fur skin was evaluated by the content of fat in the skin tissue, its welding temperature and the indicator of the formation of dermal volume in samples that were tanned using the appropriate technologies [11]. 


\section{RESULTS AND DISCUSSIONS}

To make a quantitative study of changes in protein functional groups and skin-forming components within certain characteristic waves, the optical density was determined using the baseline method [8]. The bands of $2854 \mathrm{~cm}^{-1}$ and $1454 \mathrm{~cm}^{-1}$ were selected as the internal standard due to the valence vibrations of the methylene groups $-\mathrm{CH}_{2}$ and carbon chain $\mathrm{C}-\mathrm{C}$ groups (Fig. 1). Characteristic wave frequencies for the collagen dermis of rabbit skin tissue that relate to the characteristic wave frequencies of certain functional groups or their interactions were taken into account.

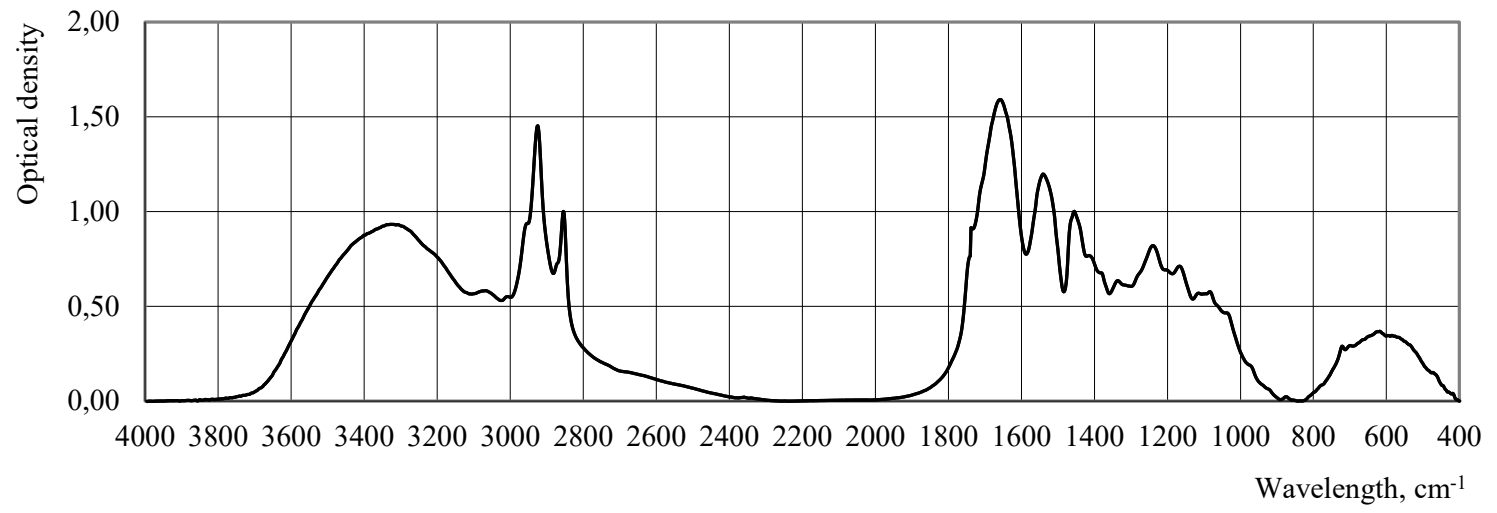

a)

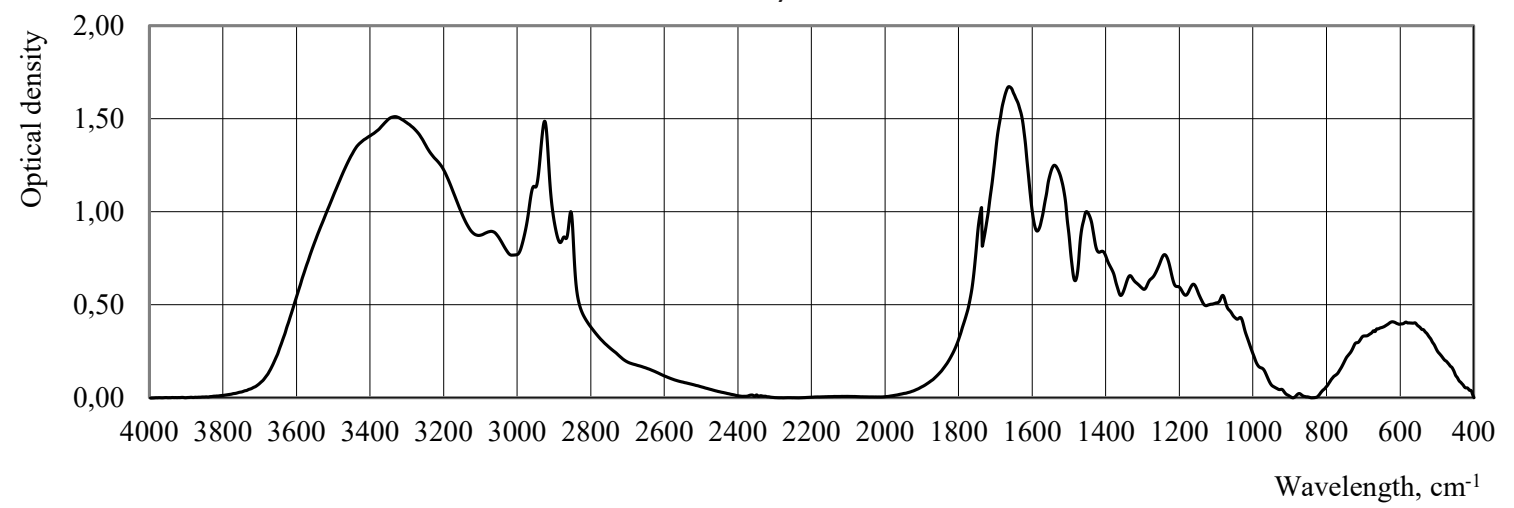

b)

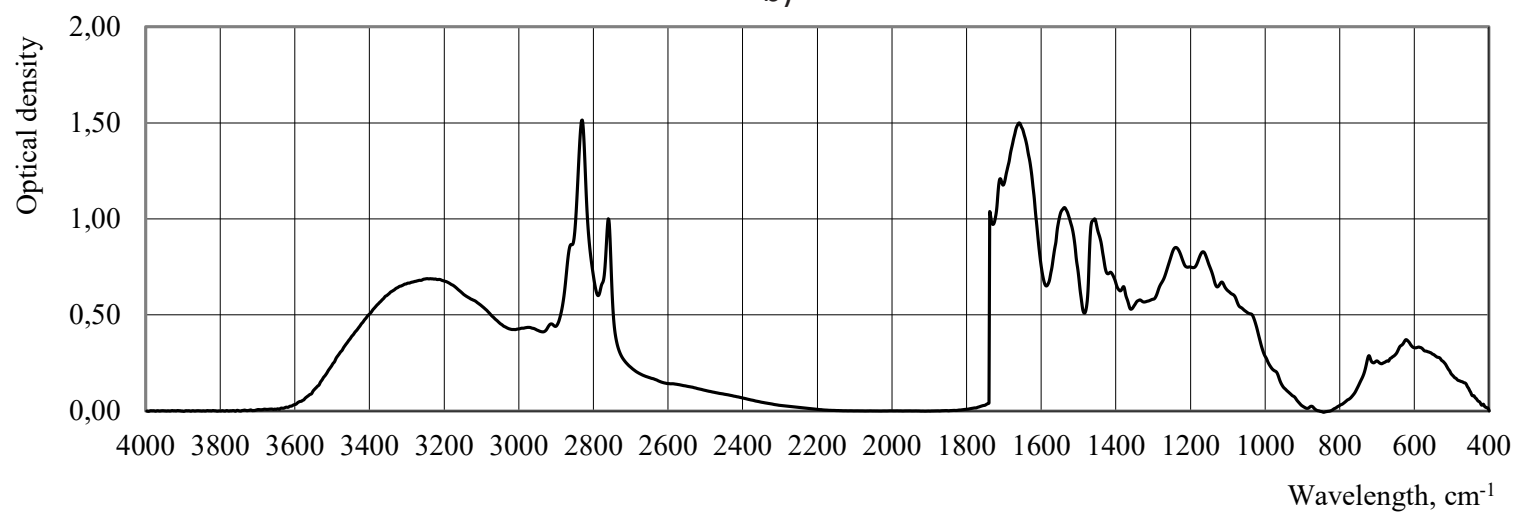

c) 


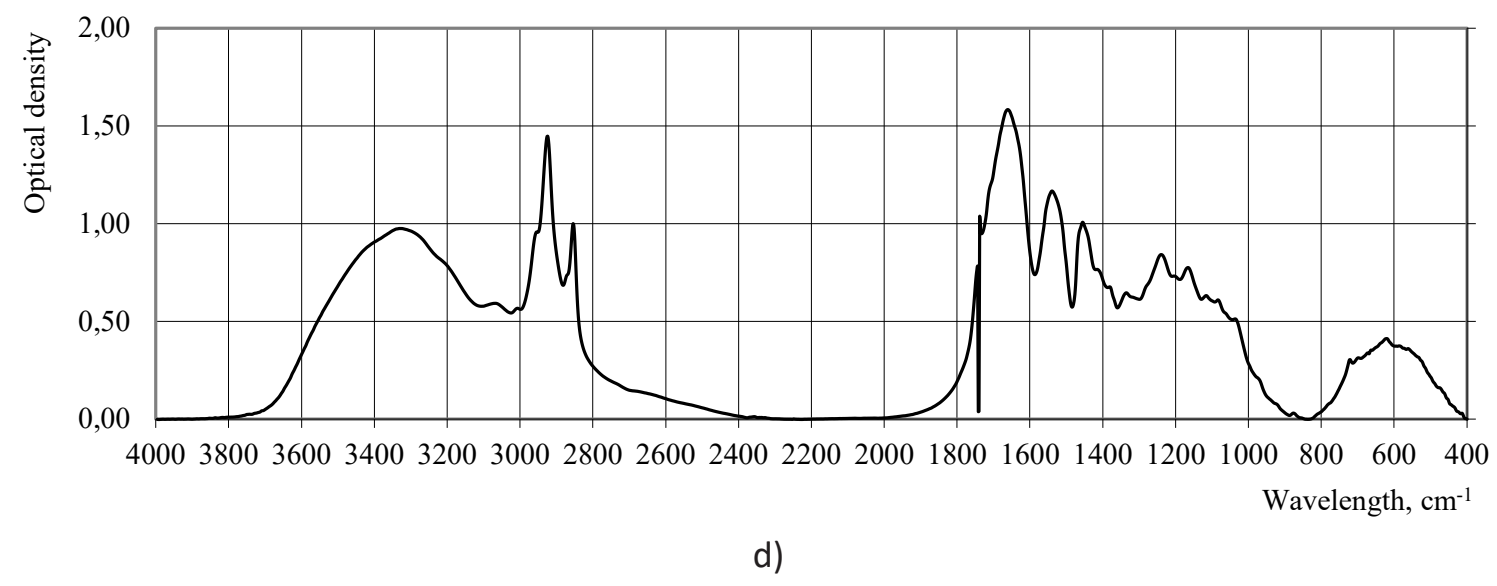

Figure 1. Experiment spectrum where the following substance was used in the technological processes: a - water formed in the result of passage of current on a negative electrode (anolyte); $b$ - water formed in the result of passage of current on a positive electrode (catholyte); $c$ - distilled water; $d$ - technical water

Tables 1, 2 show the oscillation frequencies of characteristic groups that change in the skin tissue during the manufacturing cycle of fur production. In all cases the content of neutral salts per $\mathrm{NaCl}$ was the same and was equal to $0.2 \mathrm{~g} / \mathrm{l}$.

Table 1: Optical density of skin tissue samples IR spectra in the range $3800-2600 \mathrm{~cm}^{-1}$

\begin{tabular}{|c|c|c|c|c|c|c|c|}
\hline \multicolumn{2}{|c|}{ Water characteristics } & \multicolumn{6}{|c|}{ Optical density at wave frequency } \\
\hline Water source & $\begin{array}{c}\text { Electrical } \\
\text { conductivity, } \mu \mathrm{S} / \mathrm{cm}\end{array}$ & $3410 \mathrm{~cm}^{-1}$ & $3325 \mathrm{~cm}^{-1}$ & $3246 \mathrm{~cm}^{-1}$ & $3070 \mathrm{~cm}^{-1}$ & $2926 \mathrm{~cm}^{-1}$ & $2855 \mathrm{~cm}^{-1}$ \\
\hline $\begin{array}{l}\text { Near anion electrode } \\
\text { (anolyte) }\end{array}$ & 2800 & 0,86 & 0,932 & 1,02 & 0,582 & 1,45 & 1,00 \\
\hline $\begin{array}{l}\text { Near cationic electrode } \\
\text { (catholyte) }\end{array}$ & 1270 & 1,390 & 1,51 & 1,35 & 0,89 & 1,49 & 1,00 \\
\hline Distilled water & 710 & 0,481 & 0,641 & 0,689 & 0,489 & 0,71 & 0,87 \\
\hline Technical water & 750 & 0,894 & 0,975 & 0,867 & 0,59 & 1,45 & 1,00 \\
\hline
\end{tabular}

Table 2: Optical density of samples IR spectra in the range of $1800-400 \mathrm{~cm}^{-1}$

\begin{tabular}{|c|c|c|c|c|c|c|c|c|c|c|}
\hline \multicolumn{2}{|c|}{ Water characteristics } & \multicolumn{9}{|c|}{ Optical density at wave frequency } \\
\hline Water source & $\begin{array}{c}\text { Electrical } \\
\text { conductivity, } \\
\mu \mathrm{S} / \mathrm{cm}\end{array}$ & $\begin{array}{l}1663 \\
\mathrm{~cm}^{-1}\end{array}$ & $\begin{array}{l}1539 \\
\mathrm{~cm}^{-1}\end{array}$ & $\begin{array}{l}1410 \\
\mathrm{~cm}^{-1}\end{array}$ & $\begin{array}{l}1335 \\
\mathrm{~cm}^{-1}\end{array}$ & $\begin{array}{l}1240 \\
\mathrm{~cm}^{-1}\end{array}$ & $\begin{array}{l}1166 \\
\mathrm{~cm}^{-1}\end{array}$ & $\begin{array}{c}1084 \\
\mathrm{~cm}^{-1}\end{array}$ & $\begin{array}{l}1036 \\
\mathrm{~cm}^{-1}\end{array}$ & $\begin{array}{l}633 \\
\mathrm{~cm}^{-1}\end{array}$ \\
\hline $\begin{array}{l}\text { Near anion } \\
\text { electrode } \\
\text { (anolyte) }\end{array}$ & 2800 & 1,59 & 1,19 & 0,76 & 0,63 & 0,82 & 0,71 & 0,57 & 0,46 & 0,36 \\
\hline $\begin{array}{l}\text { Near cationic } \\
\text { electrode } \\
\text { (catholyte) }\end{array}$ & 1270 & 1,67 & 1,25 & 0,78 & 0,65 & 0,76 & 0,61 & 0,58 & 0,43 & 0,40 \\
\hline Distilled water & 710 & 1,50 & 1,06 & 0,71 & 0,57 & 0,85 & 0,82 & 0,60 & 0,50 & 0,37 \\
\hline Technical water & 750 & 1,58 & 1,17 & 0,75 & 0,64 & 0,84 & 0,77 & 0,61 & 0,51 & 0,41 \\
\hline
\end{tabular}


Based on the obtained data it can be stated that water of different origin affects the spectra of rabbit skin tissue differently in the range of the spectra of $3800-2600 \mathrm{~cm}^{-1}$ and $1800-400 \mathrm{~cm}^{-1}$. These spectra are characteristic for dermis collagen tanned with basic chromium salts. Specific features of the spectrum include the appearance of $1663 \mathrm{~cm}^{-1}$ wavelength which is inherent to the valence oscillation $\mathrm{C}=\mathrm{O}$ of medium intensity, and wave of $1036 \mathrm{~cm}^{-1}$ which is inherent to the deformation oscillation C $\mathrm{O}-\mathrm{C}$ of medium intensity, which corresponds directly to the aldehyde group and the product of its interaction with the carbon chain, resulting in the emergence of heat-resistant bonds. The appearance of thermo-resistant bonds of the dermis with chromium salt can be estimated by changing the optical density at a wavelength of $1084 \mathrm{~cm}^{-1}$.

The study results proved that the technological processes of production of leather and fur skin materials, such as wetting, pickling (using technical and distilled water), tanning, greasing and drying are significantly influenced by the general characteristics of water, that can be reduced to its electrical conductivity (Tables 1-2), and the main indicators of the finished product (Fig. 2) with of the square values of the correlation ratio $\mathrm{R}$ greater than 0.8 .

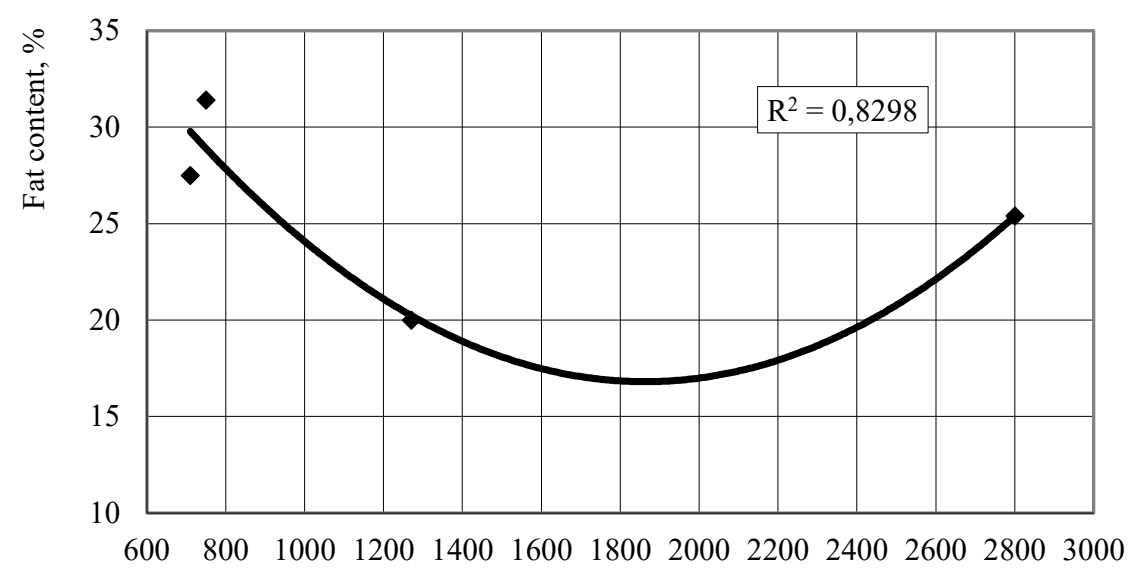

Electrical conductivity, $\mu \mathrm{S} / \mathrm{cm}$

a)

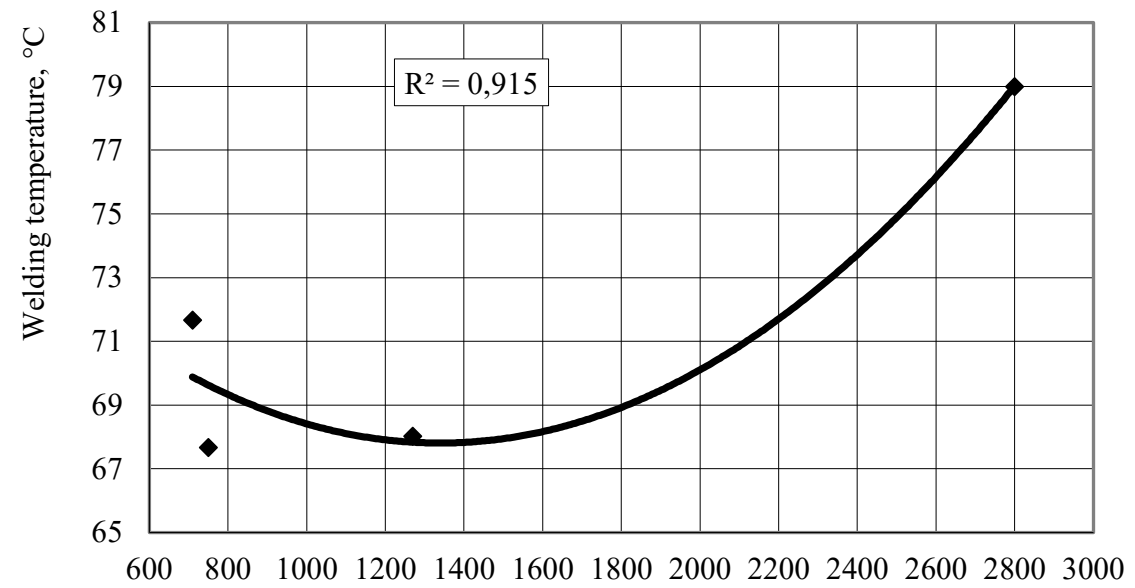

Electrical conductivity, $\mu \mathrm{S} / \mathrm{cm}$

b) 


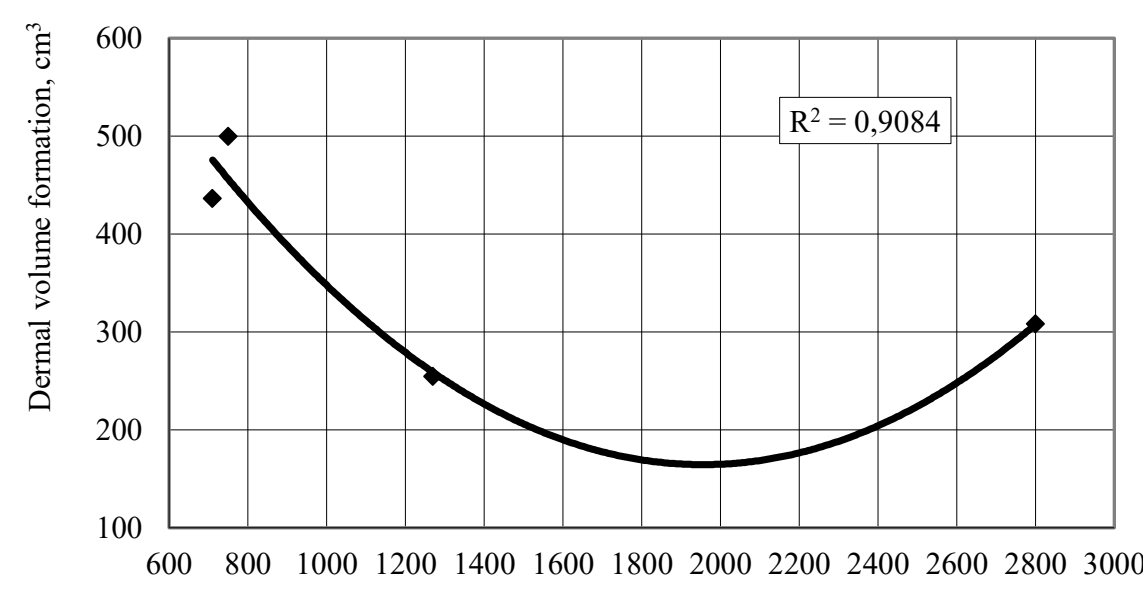

Electrical conductivity, $\mu \mathrm{S} / \mathrm{cm}$

c)

Figure 2. Water electrical conductivity effect on: a) skin tissue fat content; b) welding temperature; c) dermal volume formation

Using water with different electrical conductivity as a solvent, it was discovered that it significantly affects the degree of the polar part of both soluble substances and directly hydrophobic and hydrophilic balance inside the dermis. This leads to different interactions of the functional groups both in solution itself and between the water-soluble compounds and the active groups that are present in the dermis. The result of this interaction is a change in the analytic characteristics of the skin tissue and the index of the dermis volume formation. The positive charge of amino groups can be stated on the basis of the existence of characteristic waves with length of $3410 \mathrm{~cm}^{-1}$ and $1663 \mathrm{~cm}^{-1}$ especially in acidic environment during pickling (Fig. 3). With a certain electrical conductivity, the maximum value of the optical density can be observed. Increasing and decreasing leads to a deviation in the downward direction of the optical density when the wave oscillation frequency is of $3410 \mathrm{~cm}^{-1}$ and $1663 \mathrm{~cm}^{-1}$.

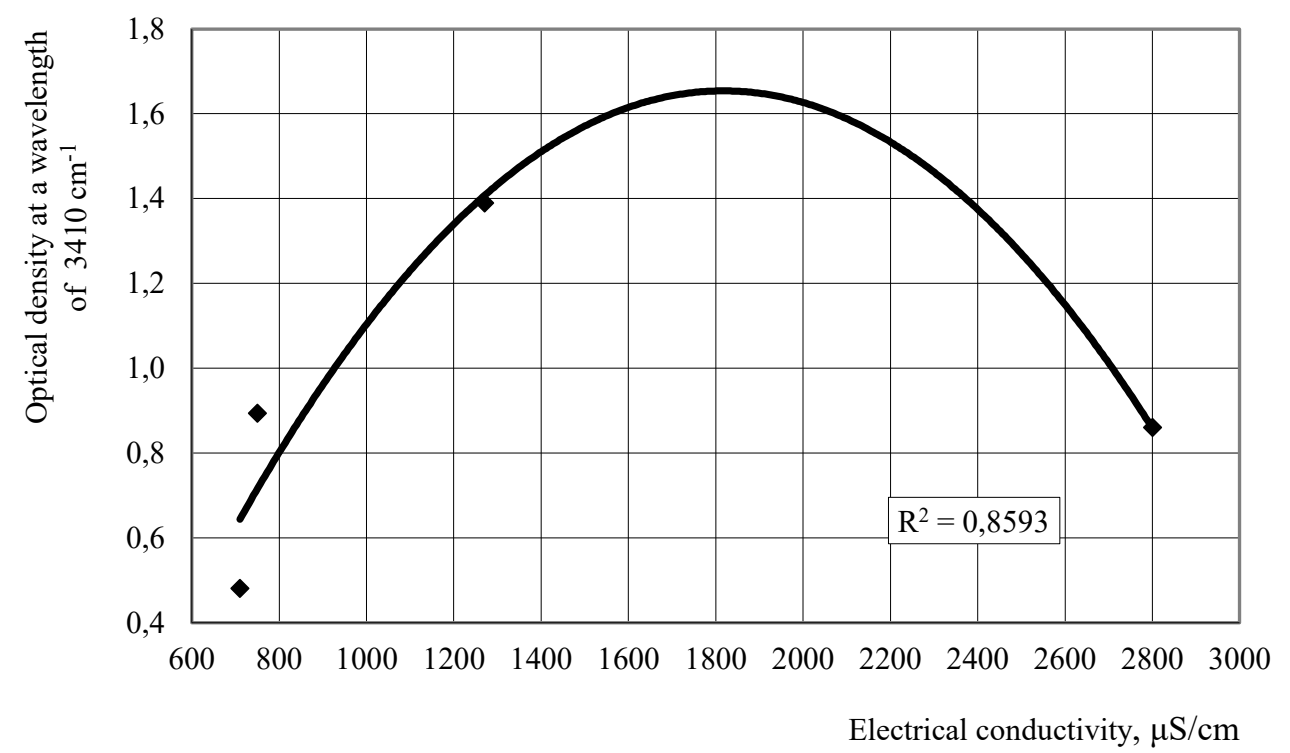

a) 


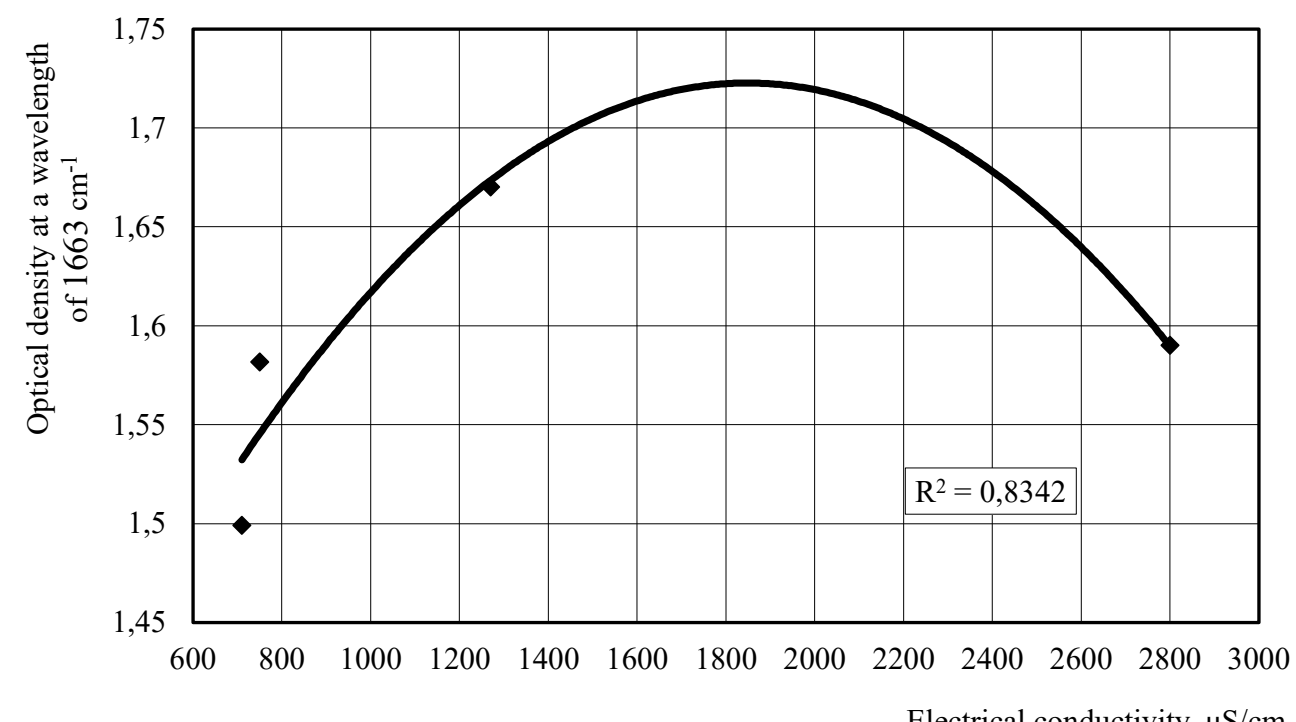

b)

Figure 3. Water electrical conductivity effect on optical density at the wave spectrum: a) $3410 \mathrm{~cm}^{-1}$;

b) $1663 \mathrm{~cm}^{-1}$

Wavelengths of $3410 \mathrm{~cm}^{-1}$ and $1663 \mathrm{~cm}^{-1}$ are associated with the formation of hydrogen bonds, a great number of which significantly affects the dermal collagen welding temperature. The essence of these connections means that after breaking in one place, they are re-formed in another place, that provides to some extent the possibility of deformation and fixing of the residual deformation.

A distinctive feature of the process of forming heat-resistant bonds in the dermis is the result of several, at first glance, opposite reactions. First of all, the normal formation of heat-resistant bonds is due to the carboxyl group being included in the chromium complex. And the interaction of the fat molecule with the chromium complexes prevents the further formation of a heat-resistant bridge. Thus, the thermal resistance of the skin tissue decreases (Fig. 4).

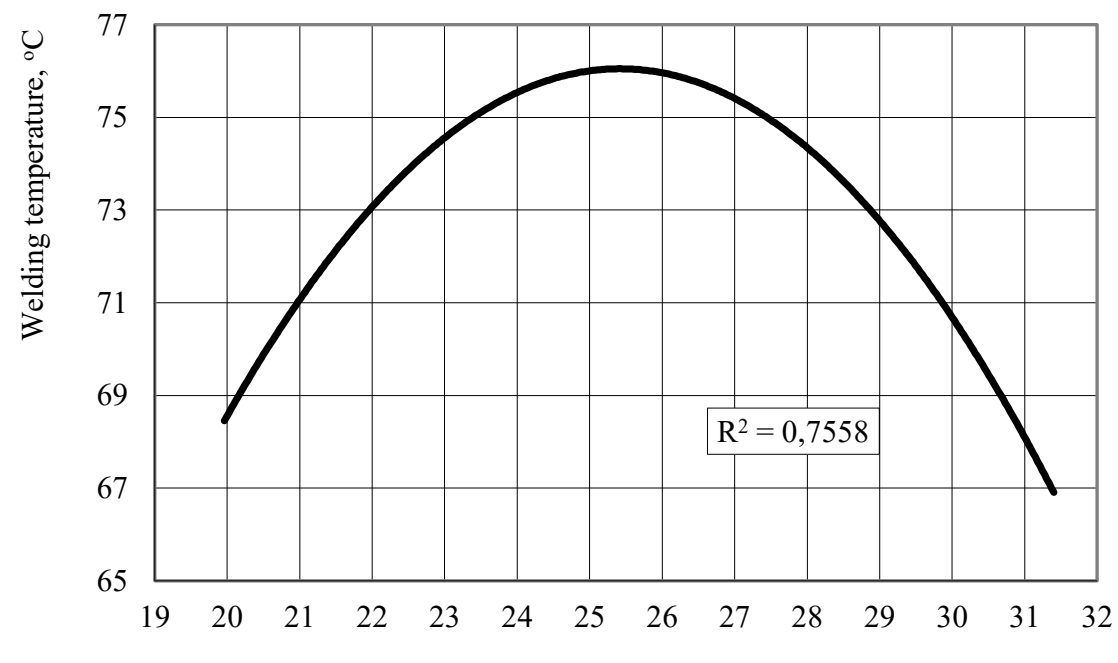

Fat content, \%

a) 


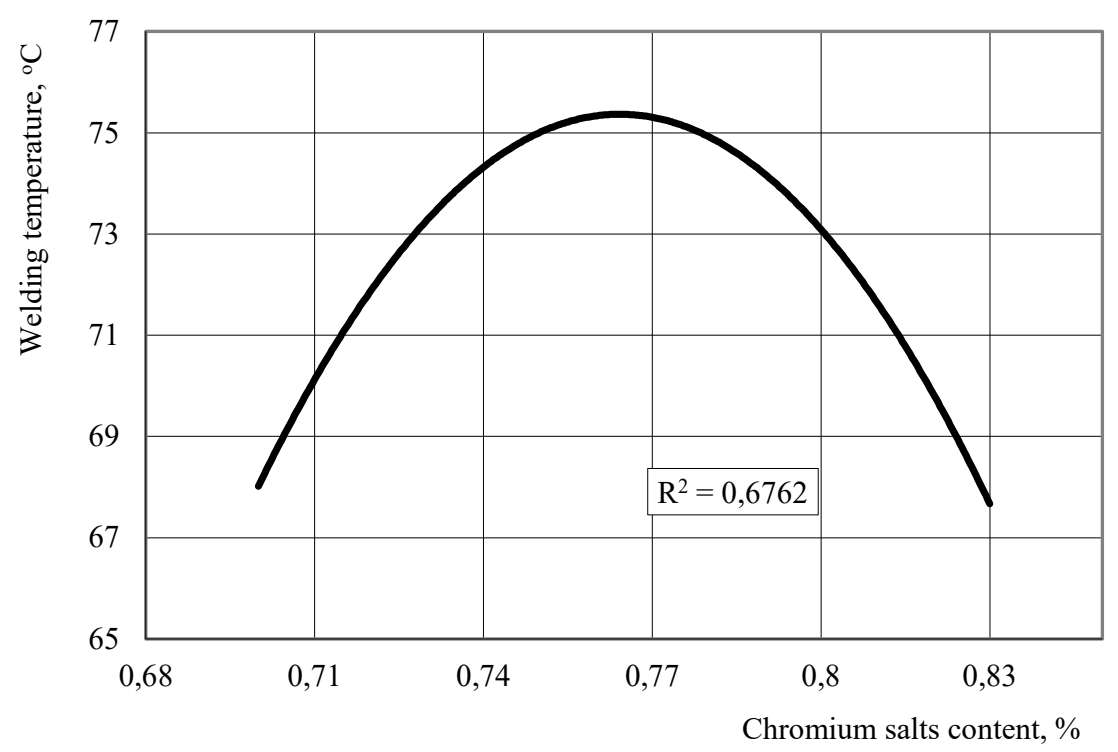

b)

Figure 4. Relationship between dermal welding temperature and: a) the fat content; b) the content of chromium salts

However, this interpretation does not explain why the properties of the skin are restored during a short period of time after welding. This phenomenon is observed when the skin is being tanned with aldehyde compounds. The appearance of $\mathrm{C}-\mathrm{O}-\mathrm{C}$ groups with a wavelength of $1084 \mathrm{~cm}^{-1}$ (Fig. 5) in the structure of the derma is a consequence of the interaction of dialdehyde compounds with protein. The aldehyde groups appear due to the presence of a large number of oxidants or reducing agents in the catholyte and anolyte in the system respectively.

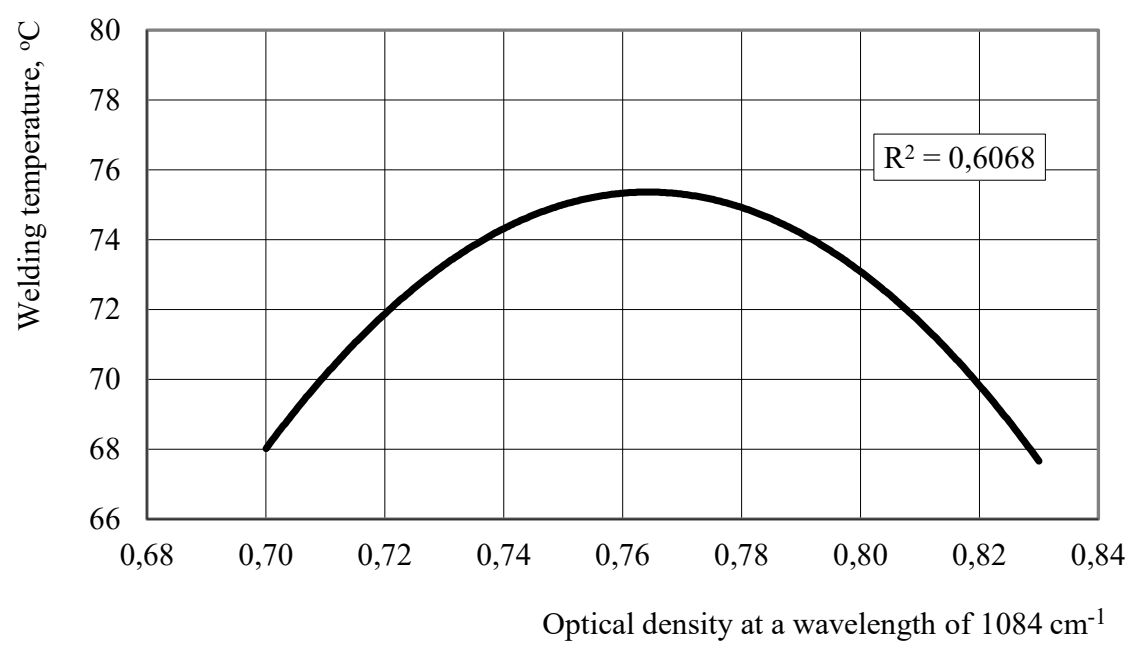

Figure 5. Relationship between dermal welding temperature and optical density wavelength $1084 \mathrm{~cm}^{-1}$

The wavelength of $1663 \mathrm{~cm}^{-1}$ corresponds to the carbonyl groups, that is conditioned by their presence in proteins and fatty substances in the form of triglycerides. Meanwhile, this wave is characteristic for the fluctuations of the $\mathrm{N}-\mathrm{H}$ protein groups, that can be manifested as a result of the transformation of the general restructuring of the protein structure in the spectrum (Fig. 6). The imprint of the restructuring (deformation under load) on the vibrations of the groups $\mathrm{N}-\mathrm{H}$ and $\mathrm{C}=\mathrm{O}$, that corresponds to the model of change in the deformation of the tensile under load and after its removal allows us to confirm the correctness of the physical model to the full extent [11]. 


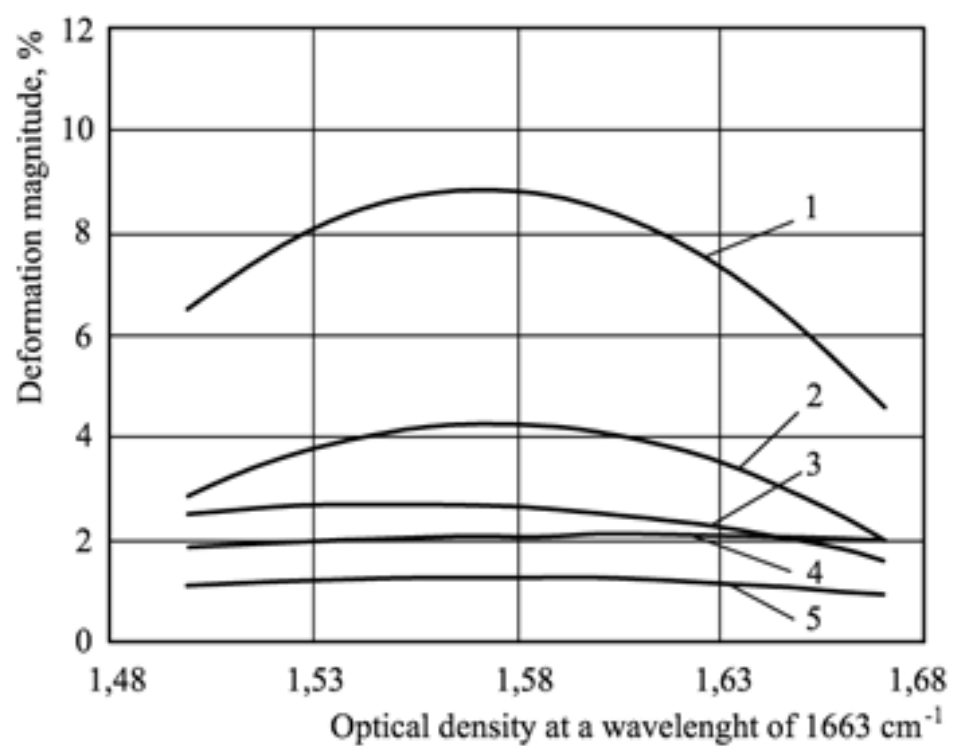

Figure 6. Relationship between the carbonyl group in the peptide bond and deformation components, \%: 1 - total deformation, $R^{2}=0,8883 ; 2$ - plastic deformation, $R^{2}=0,5975$;

3 - plastic deformation, $R^{2}=0,8196 ; 4$ - instantaneous deformation, $R^{2}=0,1341$; 5 - elastic deformation, $R^{2}=0,7061$

Negative $\mathrm{OH}^{-}$groups that are a part of the complex chromium sphere are dominated in catholyte, can result in the formation of neutral or negative charge tanner particles. The latter is most likely when using catholyte during tanning. Therefore, the negatively charged chromium molecule interacts with the positively charged $\mathrm{NH}^{2+}$ amino group, that results in the partial neutralization of the negatively charged chromium complex, freeing the coordination center in the chromium to interact with other groups having the ability of entering the complex sphere of chromium atoms. It is possible to form heat-resistant bonds in both cases that provide the effect of tanning (welding temperature increase). In the presence of trivalent chromium in a highly saturated with oxygen (in the form of $\mathrm{OH}^{-}$ions medium), the processes of oxidation of hydrocarbons with the formation of aldehydes are possible, which form heat-resistant bonds, that are destroyed at a temperature in the aqueous medium above $65^{\circ} \mathrm{C}$, and at a lower temperature below the specified level they are being restored. The appearance of such bonds is evidenced by the presence of $\mathrm{C}-\mathrm{O}-\mathrm{C}$ groups at wave frequencies of $1166 \mathrm{~cm}^{-1}, 1036 \mathrm{~cm}^{-1}$ and $1084 \mathrm{~cm}^{-1}$, that are the result of the interaction of dialdehyde compounds with the protein. The wave frequency of $1036 \mathrm{~cm}^{-1}$ can be partially attributed to the $\mathrm{OH}$ alcohol group (Fig. 7). Bearing in mind that the $\mathrm{OH}$ and $\mathrm{C}-\mathrm{O}-\mathrm{C}$ groups have a high affinity for the formation of complex compounds, it can be deduced that this effect (restoration of the sample after welding during cooling) causes the restoration of heat-resistant samples. 


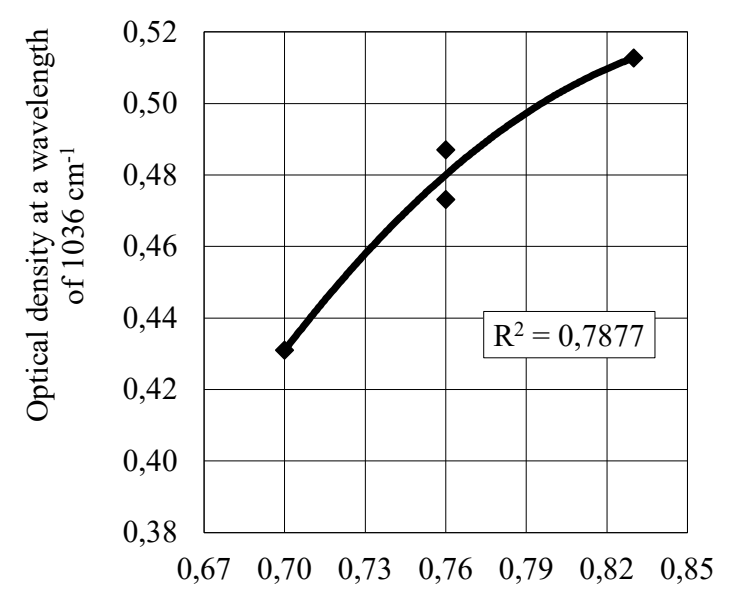

Chromium salts content, \%

a)

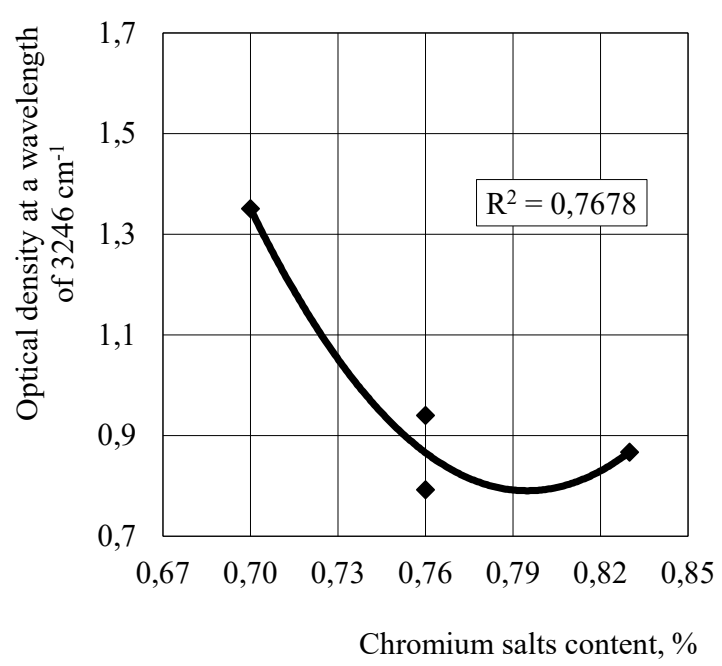

b)

Figure 7. Relationship between the content of chromium salts in the skin derma and optical density at a wavelength of: a) $1036 \mathrm{~cm}^{-1}$; b) $3246 \mathrm{~cm}^{-1}$

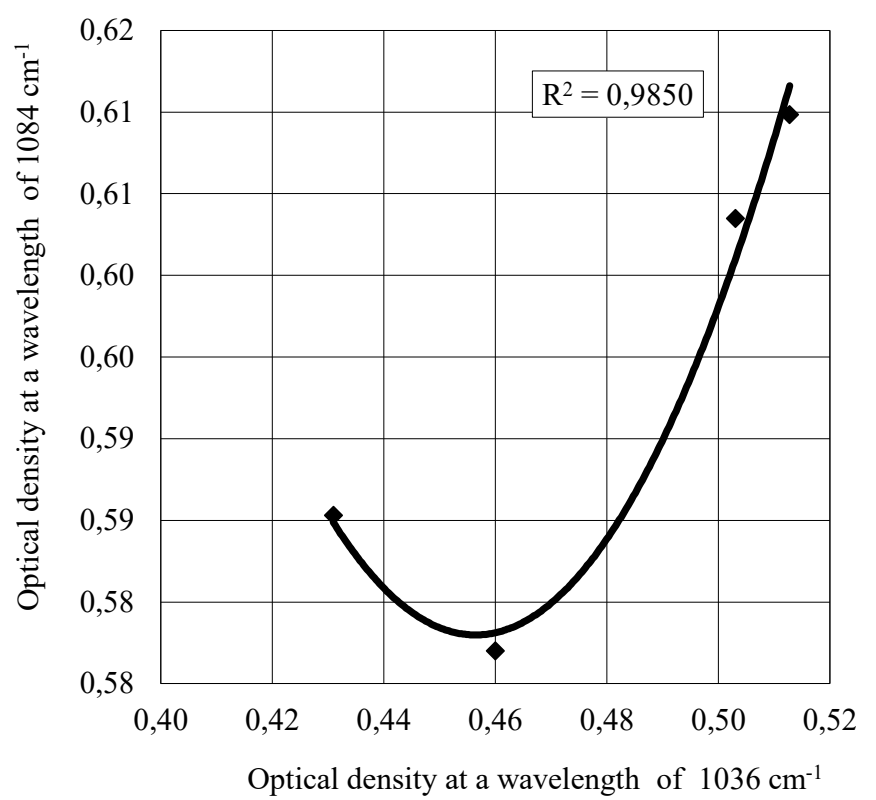

Figure 8. Relationship between optical density at $1084 \mathrm{~cm}^{-1}$ and $1036 \mathrm{~cm}^{-1}$ spectrum waves

The practical solution to the optimization problem is done almost approximate due to a large number of factors that are responsible for the results of manufacturing products and their quality. The methodology of multicriteria compromise optimization was used to final solution of the technology optimization problem. This methodology is used when there are more than two quality criteria according to which compromise optimization is performed [6].
Performing multicriteria compromise optimization requires finding a target function that looks like:

$$
\gamma_{\mathrm{tar}, \mathrm{r}}=\sqrt{\sum_{\mathrm{j}=1}^{\mathrm{m}}\left(1-\mathrm{D}_{\mathrm{jr}}\right)^{2} \cdot \mathrm{W}_{\mathrm{j}}^{2}},
$$

where $\gamma_{\mathrm{tar}, \mathrm{r}}$ - is the value of the generalized 
objective function for the $r$-th experiment experience, which in the case of finding the optimum tends to $0\left(\gamma_{\text {tar, } r} \rightarrow 0\right)$ and is a value of

the proximity of this point to the hypothetical optimal value in coded form which is equal to 1 ;

$\mathrm{D}_{\mathrm{jr}}$ - reduced to the interval $0 \ldots 1$ the value

of the $\mathrm{j}$-th response (quality criterion) in the $r$-th experiment experience, depending on the target quality selected for a specific criterion this value is calculated by different formulas;

$\mathrm{W}_{\mathrm{j}}$ - weight of $\mathrm{j}$-th quality criterion (response); practically equals to $\frac{1}{\sum \mathrm{m}}$;

$\mathrm{m}$ - the number of quality response criteria.

To find a generalized criterion for the quality of leather and fur skin materials an array of data was created which consists of analytical indicators and indicators characterizing the porous structure and deformation properties. The results of the calculation are shown in Table 3.

Table 3: Basic data to calculate the objective response function

\begin{tabular}{|c|c|c|c|c|c|c|c|c|c|c|c|c|c|c|c|c|}
\hline Group & 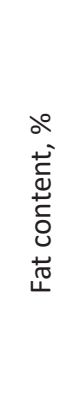 & 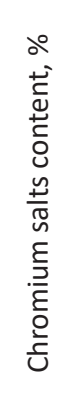 & 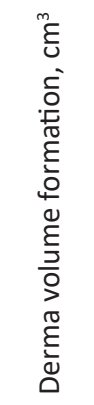 & 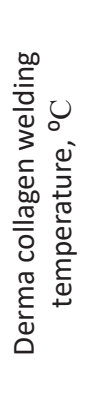 & 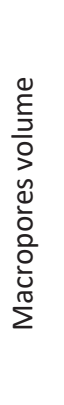 & 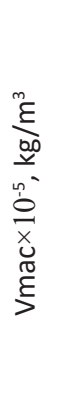 & 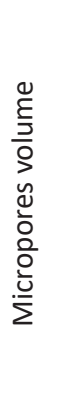 & 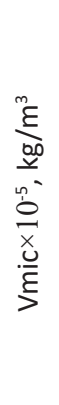 & 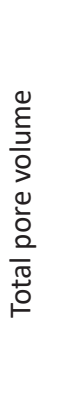 & 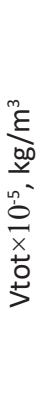 & 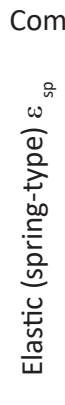 & 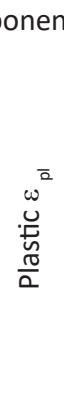 & $\frac{\sqrt[w]{\bar{z}}}{\overline{\bar{J}}}$ & 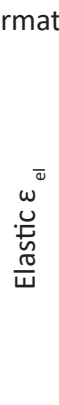 & 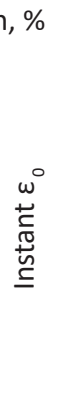 & $\begin{array}{l}\text { Overall } \\
\text { objective } \\
\text { response } \\
\text { function } \gamma\end{array}$ \\
\hline Anolyte & 25,4 & 0,76 & 308,1 & 76 & 81 & & 38,3 & & 137 & & 2,9 & 5,3 & 9,6 & 1,4 & 4,6 & 0,09 \\
\hline Catholyte & 20 & 0,70 & 254,5 & 67 & 34, & & 34,4 & & 96 , & & 1,4 & 2,9 & 5,4 & 1,1 & 1,9 & 0,21 \\
\hline Distillate & 27,5 & 0,76 & 435,9 & 68 & 30, & & 35,9 & & 91, & & 1,5 & 2,7 & 5,2 & 0,9 & 2,3 & 0,16 \\
\hline $\begin{array}{l}\text { Technical } \\
\text { water }\end{array}$ & 31,4 & 0,83 & 499,6 & 66 & 29,9 & & 34,1 & & 92 , & & 1,7 & 1,9 & 4,6 & 0,9 & 1,9 & 0,26 \\
\hline
\end{tabular}

As it is seen from the Table 3, the smallest value of the generalized quality criterion $\gamma$ (0.09) is observed in the anolyte treatment method which corresponds to the point of the factor space closest to the hypothetically optimal one.

There is a generalized dependence between the objective function, which characterizes the porous structure of the skin tissue, its analytical parameters (fat content, chromium oxide, volume formation, derma welding temperature), deformation characteristics and electrical conductivity values of the water that was used (Fig. 9). 


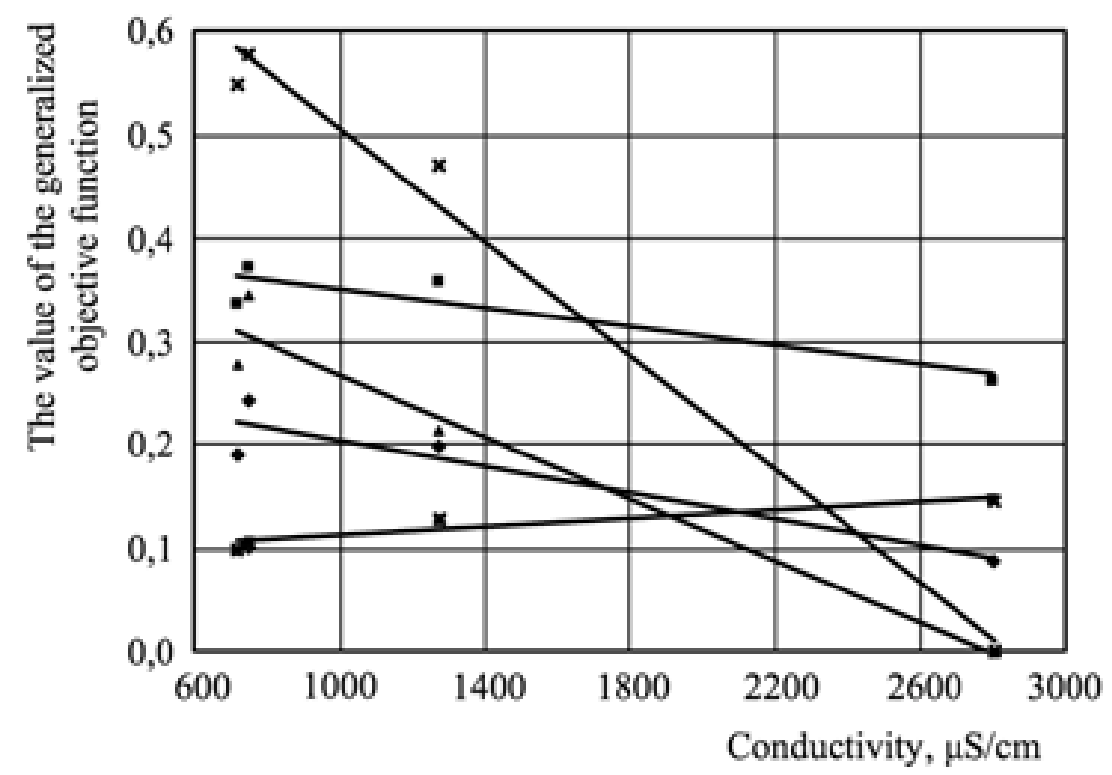

Figure 9. Effect of electrical conductivity on a generalized objective function, which is characterized by: 1 - porous structure of skin tissue $\left(R^{2}=0.9298\right) ; 2$ - analytical indicators of skin tissue $\left(R^{2}=\right.$ 0,0927); 3 - spectral characteristics $\left(R^{2}=0,9205\right) ; 4$ - deformation characteristics $\left(R^{2}=0,5613\right) ; 5$ generalized set of indicators inherent to rabbit skin $\left(R^{2}=0,6480\right)$

The spectral characteristics do not define the quality of the material, but mainly reflect the presence of functional groups that affect the parameters that characterize the quality of the finished skin. The deviation of the generalized objective function, which characterizes the spectral and analytical characteristics of rabbit skin tissue, is not significant; that is why this optimization is not taken into account.

The porosity characteristics (curve 1) and the deformation characteristics (curve 4) of skin tissue made on the basis of technologies involving the use of electro-activated water (anolyte with an electrical conductivity of 2800 $\mu \mathrm{S} / \mathrm{cm}$, catholyte with a catalyst of $2800 \mu \mathrm{S} / \mathrm{cm}$ ) are most significantly influenced by the value of the generalized objective function (Fig. 15) with electrical conductivity of $1270 \mu \mathrm{S} / \mathrm{cm}$ ) and not activated water (with electrical conductivity of $710-750 \mu \mathrm{S} / \mathrm{cm})$. When searching for the optimum, the smallest values of the generalized objective function correspond to the anolyte.

The most significant contribution to the disclosure of the essence of transformations in the skin tissue derma in the process of its manufacture is made by its spectral characteristics and porosity characteristics.

The presence of C-O-C groups (Fig. 10), which arise from the interaction of electroactivated water with the protein and the formation of aldehydes in the protein structure, which are subsequently transformed into simple heat-resistant ether bonds, has the influence on the overall objective function of the spectrum. 


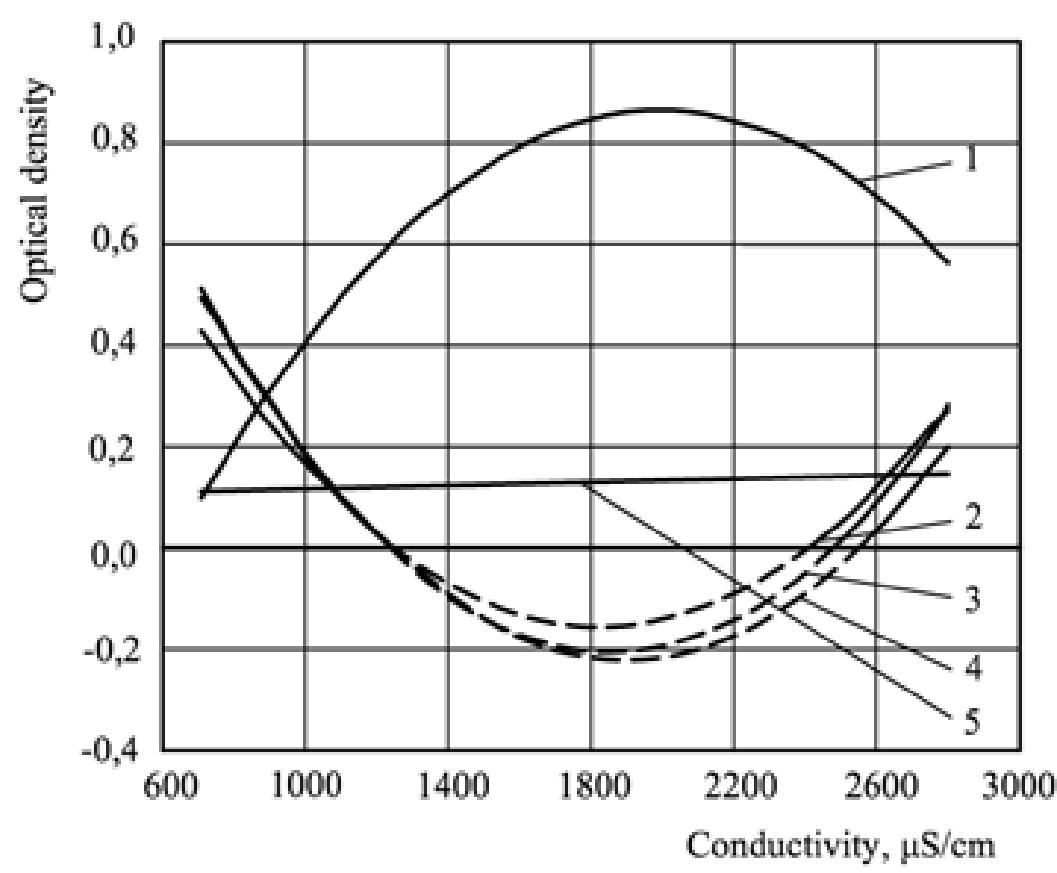

Figure 10. Effect of electrical conductivity on the optical density of the spectrum waves, characteristic for the groups: 1 - C-O-C $\left(R^{2}=0.9937\right) ; 2-N-H\left(R^{2}=0.9059\right) ; 3-C-H\left(R^{2}=0.7564\right)$;

4 - COO- $\left(R^{2}=0 ., 6402\right) ; 5$ - generalized objective function $\left(R^{2}=0.9205\right)$

The obtained optical density values (Fig. $10)$, which are lower than 0 (curves $2-4$ ), are extrapolated. They are not taken into account in the analysis because they are imaginary. Optical density limits at conductivity values up to $1260 \mu \mathrm{S} / \mathrm{cm}$ and greater than $2400 \mu \mathrm{S} / \mathrm{cm}$ are significant.

\section{CONCLUSIONS}

The treatment of leather and fur skin materials with electro-activated water in the technological cycle of their production significantly affects the quantitative indicators that objectively characterize the quality of the skin tissue (skin fat content, dermal welding temperature) and participate in the formation of skin structure (volume formation indicator), and also contributes to the elastic and plastic properties of the skin that must be taken into account when making footwear from materials with predicted properties.

The most probable reactions of the rabbit skin tissue using water with different conductivity characteristics when natural salt is present (industrial water), distilled water when table salt is present, and distilled water in the presence of table salt formed on the cathode and anode (catholyte and anolyte) are considered. The latter have shown their specificity in influencing the technological processes of fur skin production from rabbit skins. The properties of the finished skins depend entirely on the content of the components that may be the carriers of the electric charge.

The specificity of electro-activated water is that in the process of its manufacture in the anolyte an excess of electrons is observed, and in the catholyte, on the contrary, their lack is observed. This leads to the formation of compounds that have a reactive activity, that means that they interact with each other and with other active groups of collagen, which provides the appearance of cross-links in the irrigated derma that largely resistant to temperature as well as changing elastic and plastic properties of skin tissue. Thus, advanced technology can be used in industry as an effective method of leather and fur skin materials with specific properties tanning that can be predicted at the stage of their manufacture. 


\section{REFERENCES}

1. Chowdhury, M., Mostafa, M.G., Biswas, T.K., Saha, A.K., Treatment of leather industrial effluents by filtration and coagulation processes, Water Resour Ind, 2013, 3, 11-22, https://doi.org/10.1016/j.wri.2013.05.002.

2. Bordun, I., Ptashnyk, N., Chernovol, H., Investigation of the change of transmission spectra of electrochemically activated water during the relaxation process (in Ukrainian), Bulletin of Lviv University, Physics Series, Lviv, Ivan Franko National University of Lviv, 2010, vol. 45, 100-106.

3. Danylkovych, A.G., Lishchuk, V.I., Romaniuk, O.O., Use of electrochemically activated aqueous solutions in the manufacture of fur materials, SpringerPlus, 2016, 5, 1, 214-224, https://doi.org/10.1186/s40064-016-1784-6.

4. Lutsyk, R.V., Mentkovskii, Y.L., Kholod, V.P., The relationship of deformation-relaxation and heat and mass transfer processes (in Russian), Vyshcha Shkola Publishing House, 183 p., 1992.

5. Skidan, V., Nadopta, T., Mytelska, O., Yefimchuk, H., Stetsiuk, I., Yanovets, A., Method of sketch profiling with spline curves for footwear design, Leather and Footwear Journal, 2019, 19, 2, 113-122, https://doi. org/10.24264/Ifj.19.2.3.
6. Horbachov, A.A., Kerner, S.M., Andrieieva, O.A., Orlova, O.D., Fundamentals of the creation of modern technologies of skin and fur production (in Ukrainian), K: KNUTD, 190 p., 2007.

7. Vinarsky M.S., Lurie, M.V., Experiment planning in technological researches (in Russian), K: Tekhnika, 168 p., 1975.

8. Bellamy, L., Infrared molecules spectra (in Russian): Translated from English, M: Foreign Literature, 444 p., 1957.

9. Bulanin, M.O., Molecular Interaction Spectroscopy (in Russian), L: Leningrad State University, 192 p., 1970.

10. Chirgadze, Y.N., Infrared spectra and structure of polypeptides and proteins (in Russian), $\mathrm{M}$ : Nauka, 136 p., 1965.

11. Zlotenko, B.M., Savchenko, H.V., Matvienko, O.A., Use of electro-activated aqueous media in footwear production (in Ukrainian): Research Monograph, K: Kafedra, 144 p., 2012.

(C) 2020 by the author(s). Published by INCDTPICPI, Bucharest, RO. This is an open access article distributed under the terms and conditions of the Creative Commons Attribution license (http:// creativecommons.org/licenses/by/4.0/). 